\title{
TRANSLATING CHILDREN'S LITERATURE: WHAT, FOR WHOM, HOW, AND WHY. A BASIC MAP OF ACTORS, FACTORS AND CONTEXTS
}

\author{
TRADUZINDO LITERATURA INFANTIL: O QUÊ, PARA QUEM, COMO E POR \\ QUÊ. UM MAPA BÁSICO DE ATORES, FATORES E CONTEXTOS
}

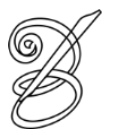 \\ Emer O’SULLIVAN* \\ Leuphana Universität Lüneburg, Germany
}

\begin{abstract}
This article presents a systematic look at the different actors, factors, and contexts involved in the field of translating children's literature. Taking as its point of departure the somewhat provocative question "Why translate children's literature?", it goes on to parse the three component parts. "Why?" involves looking at the motivation and interests of the various human and non-human actors (publishing houses, organizations, translators etc), as well as the complex interplay of geopolitical, economic, and cultural factors on publishing and literary transfer. Of the verb "translate" is asked "for whom?", to examine questions of address and its role in translation, and then "how?", to discuss determinants, strategies, and tendencies in translating children's literature. "Children's literature", the object of the translation activity, will be looked closely in response to the question "what?", to illustrate the heterogeneity of its corpus and to show that it encompasses more genres and forms than are commonly featured in studies of translated children's literature. The overall goal of the article is to provide a basic map ${ }^{1}$ of this complex field.
\end{abstract}

Keywords: Translation Studies. Children's literature. Actors. Addressees. Map.

Resumo: Este artigo lança um olhar sistemático sobre os diferentes atores, fatores e contextos envolvidos no campo da tradução de literatura infantil. Tomando como ponto de partida a questão algo provocativa "Por que traduzir literatura infantil", ele prossegue segmentando os três componentes da pergunta. "Por que" envolve observar a motivação e os interesses dos diversos atores, humanos ou não (editoras, organizações, tradutores, etc.), bem como a complexa interação de fatores geopolíticos, econômicos e culturais envolvidos na publicação e na transferência literária. Acerca do verbo "traduzir", pergunta-se "para quem?", a fim de examinar questões relativas ao destinatário e seu papel na tradução, e, em seguida, "como?", a fim de discutir os determinantes, estratégias e tendências na tradução de literatura infantil. A "literatura infantil", o objeto da atividade tradutória, será observada de perto em resposta à pergunta "o quê", a fim de ilustrar a heterogeneidade do seu corpus e de mostrar que ela engloba mais gêneros e formas do que são usualmente apontados nos estudos sobre a literatura infantil traduzida. O objetivo global do artigo é fornecer um mapa básico deste campo complexo.

Palavras-chave: Estudos da tradução. Literatura infantil. Atores. Destinatários. Mapa.

Recebido em: 18 de junho de 2019

Aprovado em: 27 de junho de 2019

Publicado em: julho de 2019 
he point of departure of this article is the question "Why translate children's
literature?". The interested and informed reader of this special issue of Belas Infieis on
Translation Studies and Children's Literature will possibly be surprised by such a simple-sounding but nonetheless provocative formulation. And could justifiably point out that translation has played a key role in the history and development of the children's literature of every country and language area, that it enriches target literatures, and exposes children to a variety of voices that is essential to widen their cultural horizons. ${ }^{2}$

Jella Lepman's autobiographical Bridge of Children's Books gives very concrete response to the question, when she relates an incident that shows why she personally translated a book in 1946. Lepman, ${ }^{3}$ a tireless advocate of international understanding through children's books, writes how her famous international children's book exhibition in post-war Germany, put together under the most adverse circumstances, was attracting huge numbers of visitors. Coming up to Christmas, during the Berlin leg of the tour exhibition, she was finding it "harder than ever to turn down children who begged for books" (Lepman 65). She decided to translate Munro Leaf and Robert Lawson's pacifist fable The Story of Ferdinand into German as 14 Ferdinand der Stier, had 30,000 copies printed on newspaper, folded into simple books, and given to the children of Berlin for free. It was "a spectacular success [...] Soon the story of Ferdinand could be heard being told on every street corner in Berlin". ${ }^{4}$ She relates how happy she was to have created the perfect Christmas gift, through translation, for the book-starved children. $^{5}$

Posed in a different tone of voice, and at a different point in history, the same question can have very different ring "Why (bother to) translate children's literature?". In the Anglosphere, some familiar arguments against translation are that there are more than enough good books written in English, translations cost money and are too great a publishing risk, it's too difficult to source and assess suitable titles and to identify appropriate translators, people don't want to read books by authors whose names they can't pronounce, and so on (Parkinson 2013). The resistance to translations in Britain and America was succinctly put by the children's publisher Dorothy Briley who remarked how the words 'Translated from the ...' on the title page of a book "is code for 'admire but don't buy it"” (Chambers 114).

These two very different types of response touch on aspects of what I will address in this article. Taking "why translate children's literature?" as my starting point, and parsing the three component parts (see Figure 1), I would like to chart the complex field of children's literature translation. What follows is neither a summary of existing theories of children's 
literature $^{6}$ or literary translation ${ }^{7}$, nor the formulation of new ones, but an attempt to identify, in a systematic manner, the multifarious factors that are in play when we talk about the field of translating for children.

Figure 1 - Why translate children's literature

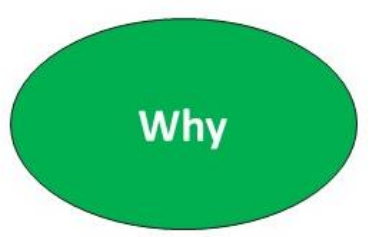

Motivation of

(human and

non-human) actors
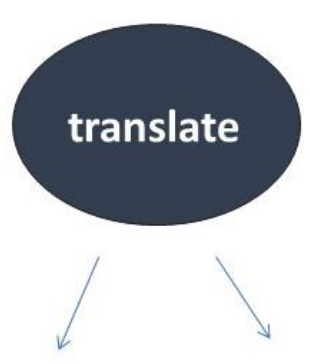

For whom? children's

literature

Factors which

inhibit translation

(= 'why not?')

The component parts of the question are:

Why. This question leads us to actors - both human and non-human - in the field of children's literature who are involved in publishing, promoting, advocating, translating, or otherwise disseminating translated children's literature, and their various motivations or reasons for involvement in the field. The question "why?" also addresses factors that may explain why children's literature is not transmitted (in other words, "why not?"), looking at the complex interplay of geopolitical, economic, and cultural factors that can inhibit translation.

Translate. This is split into two parts; one asks "for whom?", and centers on the aspect of the addressees or implied readers of children's literature; the other asks "how?", to examine the norms that influence and the strategies used in translation for children.

Children's literature. Of this, the object of translation, we must ask “what?": What is children's literature? What constitutes its corpus? The discussion of children's literature in translation has, to date, not always differentiated sufficiently between or paid attention to all its heterogeneous elements.

In what follows, these elements will be addressed in reverse order, starting with "children's literature" and finishing with "why". 


\section{Children's literature: what?}

What children's literature is not: Children's literature is not a homogenous body of texts characterized by features of content, style or form shared by every book in the corpus. Its sole common denominator lies in its audience and in those who engage with it: children's books are texts that are produced or deemed appropriate for children by adults.

The noun "children's literature" denotes a broad range of heterogeneous texts with different sources, addressees, types, genres and forms, and functions (see Figure 2). Its sources are folklore (folk- and fairy tales), books originally for adults and subsequently adapted for children, books authored specifically for children, and other media in the form of tie-ins. It addresses readers from infants to young adults - and sometimes also adults either as mediators or as readers in their own right of crossover or 'all-age' books. The types of books (relating to format, appearance etc.) include multimodal picturebooks, comics, pop-up books, anthologies, novels, and multimedia hybrid books. Amongst its genres and forms are adventure stories, science-fiction, horror, information books, plays and poetry. Its degrees of linguistic complexity range from concept books with a single word per page through beginner readers to sophisticated of children's books are the different functions they fulfil. These include the primary function of teaching children how to read and promoting literacy, helping them to go to sleep (lullabies, bedtime stories), amusing and entertaining them, informing and educating them, and stimulating them intellectually and aesthetically. Very different types of texts of course, address these different functions.

Figure 2-Children's literature: what?

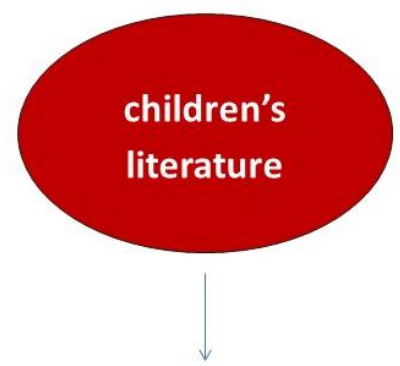

What?

Sources: folklore, adult literature, specific children's literature,

other media

Addressees: infants to young adults

Types of books: pop-ups, anthologies, multimodal texts

Genres and forms: adventure stories, science- fiction, plays,

poetry ..

Functions: aesthetic, entertainment, promoting literacy,

educational

O'SULLIVAN, Emer. Translating children's literature: what, for whom, how, and why. A basic map of actors, factors and contexts. Belas Infiéis, Brasília, v. 8, n. 3, p. 13-35, 2019. 
Talking about the "what" of children's literature reveals its heterogeneity, its vast plurality of types, forms and functions. The proportion of each in any given source language will not be the same as that in the corpus of translated children's literature. Poetry for children is rarely translated (Kreller), for instance, while picturebooks ${ }^{8}$ belong to the most translated (Hallford), as they are thought of as requiring less in the way of translation ${ }^{9}$ and offer greater opportunities for international co-production, which makes them more economically viable than novels for older readers. ${ }^{10}$ Nonetheless, the range of types of children's books is not reflected in most articles and books about translating children's literature, that often focus on a single genre and seldom consider or address the full range of types of texts the term encompasses, and the consequences this breadth has for the topic of translating for children.

\section{Translate}

The questions "for whom" and "how" are inextricably interrelated. Both the imagined target reader and the idea of what is suited to their capacities on the one hand (the "who"), but also the norms of the target culture and literature on the other, that partially determine how any given text is actually translated and which strategies are applied (the "how") (see Figure 3).

Figure 3 - Translate: for whom and how

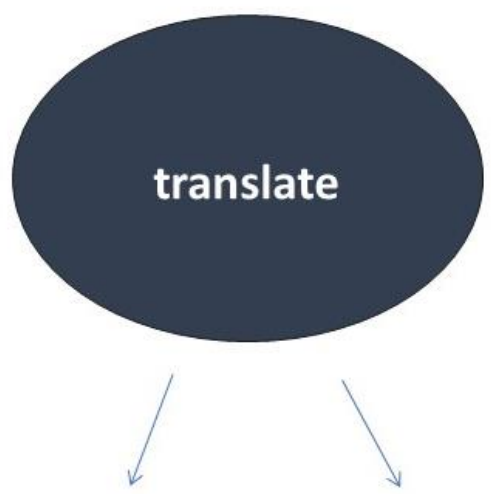

\section{For whom?}

The implied reader of the

translation, determined by

considerations of

cognitive, emotional and

linguistic development

„appropriateness" or

„suitability" of content or

form
How?

Norms:

linguistic

character and behavior

physicality

content

Strategies:

omission and deletion

purification

substitution

explication

simplification 


\subsection{Translate: for whom?}

The answer to the question "for whom?" can sound fairly obvious: For children of whatever age or young adults, depending on the source text. But it is not quite as simple as that. As books that are produced or deemed appropriate for children by adults, children's books are defined by their audience and by those who address that audience. The unequal or asymmetrical relationship arising from the assignment of texts by adults to children, the "power difference between adult mediators and child readers" (Alvstad 2019, 159), is a constituent element determining many of the essential differences between children's and adult literature. ${ }^{11}$ Ostensibly addressed to young readers, children's literature is written, translated, published, reviewed and recommended by adults. Adult librarians administer children's books, teachers use and encourage the use of them, they are purchased by parents, uncles, aunts etc. This mediating role of adults is a vital one without which children would have no books at all. But a children's book must gain adult approval if it is to be recommended or translated, it must be regarded as appropriate for the children in that particular target culture at that particular point in time.

18 Children's literature has to take into account the needs, capabilities and interests of its readers. Amongst the distances between adults and children that have to be bridged in and by it are: command of language, experience of the world, and literary knowledge. It therefore adapts language, subject-matter and thematic and formal features to allow for the children's stage of development, knowledge and repertory of skills acquired, and interests. These cognitive and emotional developmental issues and the actual receptive ability of child readers are at the heart of children's literature translation, and they are connected to a central paradox. A commonly recited belief is that books are translated in order to enrich the target literature and to introduce children to foreign cultures. However, it is exactly these foreign elements that are often eradicated from translations heavily adapted to their target culture, or "domesticated" (Venuti), allegedly on the grounds that young readers won't understand them. Many translated texts underestimate child readers, wanting to "protect" them from being over-challenged by elements they may not (yet) understand, resulting in "nanny translations" (O'Sullivan 1999, 170). What children at any given stage in their development can actually understand, and how much "foreignness" they can and do cope with is the ultimate black box of translating for children. As Gillian Lathey has rightly pointed out, a greater emphasis on empirical research into reader response would inform current speculation (Lathey 2006, 12). Translated children's literature is therefore the result of a balancing act by translators (understood in the broader sense to 
include editors, publishers etc.) between adapting foreign elements to the child reader's level of comprehension, and preserving the differences that constitute a translated foreign text's potential for enrichment of the target culture.

The implied reader of the translation is always a different entity from the implied reader of the source text (O'Sullivan 2003), and is constructed according to the answers translators and publishers provide in a given time and culture to the questions: What do children want to read? What are their cognitive, emotional and linguistic capabilities? How far can/should they be stretched? What do they enjoy? But also: What is suitable for them?

Besides the developmental issues determining the construction of the implied target reader is the issue of appropriateness of content or form. As "children's fiction belongs firmly within the domain of cultural practises which exist for the purpose of socializing their target audience" (Stephens 8), the social, cultural and educational norms, and religious and political values dominant in a given culture at that specific time influence both what is selected for translation, and how it is translated to make it appropriate or suitable for the children in that culture at that time.

\subsection{Translate: How?}

Translating for children differs from translating for adults only in the degree "to which it necessitates or allows forms of textual manipulation" (van Coillie and Verschueren, "Editors' Preface" v). ${ }^{12}$ Manipulations in children's literature can be morally, ideologically, or educationally motivated. The forces behind them can be state censorship in totalitarian regimes such as former communist East Germany (or German Democratic Republic) (ThomsonWohlgemuth) or the fascist regimes in Italy (Sinibaldi) or Spain (Fernández López), or selfcensorship in deference to perceived norms. It is more difficult for translators than for authors to challenge established norms, and "translations are generally more conservative than original literature produced in the same context" (Alvstad 2019, 170).

The chief norms that influence children's literature translation are

- linguistic norms that govern the use of language considered appropriate - playful misspellings, for instance, are often corrected in translation, and slang and informal registers translated into more formal ones, ${ }^{13}$

- norms of characterisation and what is considered appropriate behavior that may lead to modifications - a famous examples being the toning-down of the rebellious, subversive behaviour of Astrid Lindgren's Pippi Långstrump (1945) in early translations, ${ }^{14}$ 
- norms relating to physicality that determine which parts of the body and its functions may be shown in a picture book $^{15}$, and

- norms of content that come to bear on the topics deemed acceptable in children's books (see Alvstad 2018 for a discussion of interventions that take place motivated by the issues of violence, religion, racism and sexuality).

The different strategies for manipulation applied by translators for children were systematized as follows by Mieke Desmet, based on the work of Göte Klingberg, Zohar Shavit and others. They include

- omission and deletion strategies, linked to the ideological goal of transmitting appropriate values to children, as well as to the goal of making a text easier to understand for its young audience,

- purification strategies to bring translated texts in line with the values of the target culture by purging elements considered inappropriate,

- substitution strategies, to provide children with easily intelligible texts - this is what Klingberg called "cultural context adaptation" and Venuti "domestication",

- explication strategies, including rewording or paratextual explanations, and simplification strategies that, on the macro-structural level affect genre affiliation, structure and organization in chapters, and on the micro-structural level take the form of using short sentences, substituting concrete for abstract language, weakening ironic elements and so on (Desmet).

Not all 'manipulations' and interventions should be seen in negative terms. As Alvstad writes, "[f]or ethical reasons, some alterations may at times be necessary if a given work is to be published, be it only because children's frames of reference about the real world and their rights in it are more limited. Children may for example have limited knowledge about their right not to be physically or sexually abused, and this will affect how they interpret violence and abuse directed at fictional children in books." (Alvstad 2019, 163)

Context and genre may also call for a more differentiated approach to the question of 'manipulation'. As translator Anna Becchi writes, if in a text for first-grade readers the "characters have funny names with particular meanings as well as relating puns, then even a localization of the text - which means a changing of the setting to a more familiar one - may 
be the most appropriate choice" (Becchi 62). Performative texts like poetry or read-aloud picturebooks may demand more licence. This the source text publisher readily granted this to the Irish poet Catherine Ann Cullen for her translation of the illustrated collection of poems by Latvian poet Inese Zandere on being unwell or injured. Both names appear as co-authors of All Well (Little Island Press, 2019) together with that of illustrator Reinis Pētersons (Cullen). Translator Daniel Hahn talks about his translation of Éric Veillé's rhyming L'encyclopedie des mamies (2018) in performative terms: it "is so playful, and requires a lot of inventiveness - or, to put it another way, it requires changing a great deal. I left *everything* out if you want to think of it like that, except for the spirit of the original, which I hope is there, alive and intact. [...] It's a fun game" (TRANSLATION). ${ }^{16}$

By the same token some information books not only allow but demand some degree of domestication. Valerie Wyatt's award-winning humorous non-fiction book about nation building, How to Build Your Own Country, was translated and adapted for a German readership by Petra Buck. It explains forms of government, elections, constitutions etc., so it was necessary for the translator to localise this kind of information to make it relevant for young readers. And, because Buck takes a "bath-mat republic" as her example of the nation German readers could build for themselves at home, and this involved using a totally different set of images from the source text, the German version, Die Bademattenrepublik. Anleitung zum Aufbau einer eigenen Demokratie (Klett Kinderbuch, 2014), was newly illustrated by Volker Fredrich.

\section{Why (translate)?}

The question "why?" asks what motivates the different actors - human and non-human - in the zone of translating for children - publishers, organizations, translators etc. It also leads to larger questions relating to economic, geopolitical, and cultural factors influencing the creation and distribution of translations, and they necessarily involve looking at the flipside of the coin to examine factors that impede translation, in other words to ask the question "why not?". What follows is not an exhaustive account of everyone involved in translating children's literature, from the publishing conglomerate through literary agents down to the last gatekeeper of children's literature. Instead, it will look specifically at the motivation of the human and nonhuman actors directly involved with, or with an interest in, producing or disseminating translation, as well as factors that may inhibit or prevent translation (see Figure 4).

Why any individual book may or may not be (re)translated can be influenced by all kinds of factors. A legal issue, such as a copyright expiring, allowing (re)translation without a 
license, can be a catalyst. When Saint-Exupéry's crossover novel The Little Prince entered the public domain in 1994, three new English translations came out immediately. Further factors potentially supporting (re)translation of an original work include the release of a film or other media adaptations. This was the case with Lucy Maud Montgomery's Anne of Green Gables, that had to wait 76 years before it was translated into German - as a tie-in to a tv adaptation (Seifert). And sometimes it may simply be a case of serendipity. ${ }^{17}$ A recent translation success story involved a German girl living in London, who wrote to the publisher Barry Cunningham at Chicken House, to ask why there wasn't an English version of her favourite book, Herr der Diebe, by Cornelia Funke. Funke, at that point a successful author in Germany, but still unknown in the English-speaking world, had actually had a translation already done at her own expense, that Cunningham then read and subsequently published. The Thief Lord went on to win the Batchelder Award the following year, was released as a major film in 2006 and it, as well as subsequent novels by Funke, stormed the New York Times' children's bestsellers, earning Funke the epithet "Germany's J.K. Rowling”. The girl who got the ball rolling rightly deserved the gratitude expressed in the publisher's preface: “And a special thank you to Clara

Figure 4 - Translate: 'Why' and 'why not'

Actors and motivation

Publishing houses

- Organizations

- national funding agencies

- non-profit organizations and

charities

- prize-awarding bodies

- Translators

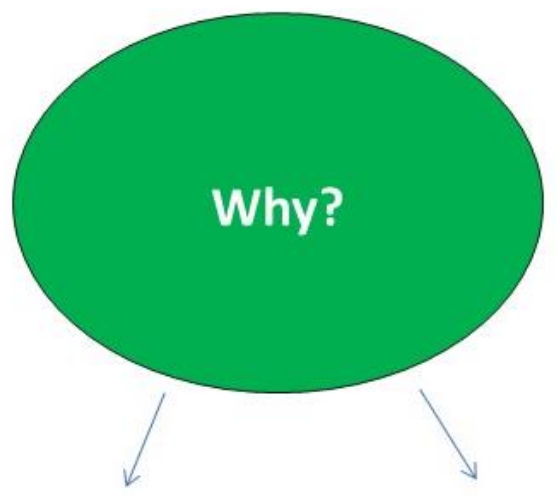

Factors which inhibit

translation $\left(E_{n}\right.$ why

not?")

- geopolitical

- economic

- cultural 


\subsection{Why: Actors and motivation I}

However, these aspects are relatively insignificant compared to the systematic ones pertaining to the global publishing market. Mergers and acquisitions, creating synergy effects and media convergence, are dominant contemporary commercial strategies. According to Ann Steiner, the six largest publishing corporations in the world in 2015 were Pearson, Thomson, Reuters, Reed Elsevier, Wolters Kluwer, and Penguin Random House, all of them media conglomerates. Links between publishing and the film and entertainment industry has been strengthened by mergers, and cross-media synergies with tie-ins, merchandise etc. have become increasingly important for all forms of book publishing, "but particularly in certain segments such as young adult" (Steiner). For these corporations, publishing is only a small section of their entertainment business, "the book has become but one of many products in the large-scale media company" (ibid.).

The immense growth, the constantly increasing number of published titles per annum makes it harder for individual books to be noticed, and their shelf life is becoming increasingly short. Steiner observes that from the publishing perspective most books have 6 months to succeed, and many books cannot be accessed at all after 2 years. Global publishing, with its eye on the world market, has become even more reluctant to take on translations unless they have a proven international track record. Since the phenomenal success of Rowling's Harry Potter series, children's publishing everywhere has become even more market driven. ${ }^{18}$ Children's authors complain that the goal posts in terms of sales have shifted since Harry Potter, and that the book market has polarised into an "all or nothing" scenario with publishers chasing the next big global seller. This increased pressure for large-scale commercial success has meant that many middle titles are squeezed out.

The proportion of translations in the annual production of children's literature in different countries ranges from between $1 \%$ to $80 \%$. A variety of factors, other than the concentration and globalisation of publishing just mentioned, determine why more is translated in some countries than in others. Cultural factors can be the revival of a language, when it becomes the official one of a newly-founded state or autonomous community, and the provision of (children's) literature in that language becomes a major priority in terms of language politics: a language unable to look back on a long tradition of published writing has to depend on translations to enrich and expand its literature. This was the case with translation into modern Hebrew in Palestine at the beginning of the 20th century (see Shavit), with translation into Irish (Gaelic) in Ireland after 1922 (O’Sullivan forthcoming) and, more recently, with translation 
into Galician (Millán-Varela). In such cases, translations support and encourage indigenous literary growth, and their proportion will often decrease as the indigenous literature develops. Generally speaking, small languages are often more dependent on translations than major ones, as the pool of authors in their languages is small.

At the bottom of the league table of countries that translate are the Anglophone countries: Britain with around $3 \%$ and the USA with around $1 \%$. The lack of translations, Nicholas Tucker has this called "a British problem" (Tucker), is well documented and the reasons often rehearsed (cf. the contributions in McMartin and van Coillie). However, it should also be noted- as Daniel Hahn pointed out in 2007 - that $3 \%$ of a market as huge as the British one is a lot more in terms of numbers of titles than, say, $30 \%$ of a market in a country that produces significantly fewer books (Hahn).

Heading the league table in Europe are the Scandinavian countries before Eastern European countries such as Poland and the Czech Republic ${ }^{20}$, followed by the Netherlands, Italy and Germany in the midfield. As the third highest producer of published print titles per annum in the Western world, after the USA and Britain, Germany has always served an

24 important function in mediating translation. But how diverse are the literatures that are welcoming towards translations? Some $45 \%$ of the total of books published for children in Sweden in 2016 were translations (Alvstad 2019, 173), seemingly indicating that children's books from several countries find their way easily into that literature. But as Alvstad remarks, referring to a report by the Swedish Institute for Children's Books, "the system is open above all to books originally written in English, with as much as 70 per cent of the translations stemming from English and with Danish, German, French and Norwegian together making up 25 per cent of the books. Books from other (or unspecified) language areas make up only 5 per cent" (Alvstad 2019, 173). According to the report, "translations from parts of the world outside of the West are almost entirely lacking" (ibid.).

\subsection{Why not [translate]? Inhibiting factors}

This leads us to the question "why not?": why are books from minor languages or from countries perceived as "far away" not translated? Relating to the Swedish non-translation, Alvstad asks: "Is it because no works considered of merit stem from such areas? Or is it because of a lack of networks or knowledge among publishers and literary agents? Or is the foreignness in itself considered to be too difficult or too strange to appeal to Swedish readers?" (Alvstad $2019,174) .{ }^{21}$ We can ask the same questions in relation to the lack of presence of these 
literatures in other translated children's literatures as well. Geopolitics and differences in economic and cultural capital all have a bearing on the extreme imbalance in the international circulation of children's literature. The hierarchical system governing translation flow, according to Johan Heilbron, determines that translations flow outward from languages occupying central positions in the system, with only a limited number travelling in the opposite direction (Heilbron).

Many literatures cannot partake as sellers in the international market, because they are not (yet) in a position to be able to serve their own, local one. The situation in what he calls "the developing countries of Africa, Asia, Latin America" is characterised by Michael Daniel Ambatchew as follows: "weak publishing sectors, inadequate distribution mechanisms, and poor purchasing power all contribute to a severe shortage of quality indigenous reading materials" (Ambatchew 431). He specifically accuses international publishers of being "more devoted to their profits" and of viewing Africa "as a small export market, rather than a partner in the publishing arena whom they should support and mentor, and with whom they can collaborate". One can see how difficult it is for African publishers, especially in smaller, local languages, to become economically viable when on estimate between 1988 and 1991 alone Africa imported US\$ 769 million worth of books from the EU; in addition to this, organizations such as Book Aid International donated millions of books. These countries are simply overseas markets for large quantities of English-language books sold by the globalised publishing industry sells without translation into local languages or mediation by a local publisher. But even in countries where literature is translated into the local language, the vast amount of foreign titles on the market causes some commentators, such as Sabeur Mdallel, to fear for the loss of local culture and children's literature: "The waves of translated books, filling the markets in the Arab world prevent the spread of local children's literature" (Mdallel).

\subsection{Why: Actors and motivation II}

Leaving this zone of "why not?" to return to "why?", we find, at the opposite end of the publishing spectrum from the global conglomerates, publishers and organizations who seek to enable geopolitically disadvantaged literatures to find a place - however small - in the Western world. One of these is the Swiss charitable organization "Baobab Books", committed "to promoting cultural diversity in children and youth literature" and standing for "solidarity and equal opportunities in global society". ${ }^{22}$ For over 25 years they have been translating into German children's books from Africa, Asia, Latin America, Oceania and the Middle East, with 
a special focus on indigenous literature. Another is the Danish publisher Vagn Plenge, proprietor of the Forlaget Hjulet ('The Wheel Press'), who, since 1976, has been purchasing translation rights and books from countries in Asia, Africa, Latin America and Oceania and initiating co-productions (Jensen). His answer to the question "why publish translated children's books?" is: “in order to [...] bring in stories and/or pictures - images - from other cultures, to promote understanding, appreciation and respect for other people and their values and way of life" (Plenge 426). He calls it "cultural bridge-building work". ${ }^{23}$

So the publishing spectrum ranges from purely commercially motivated global conglomerates with no interest in cultural mediation, to altruistic publishers and organizations that try to redress, even if only on a tiny scale, the geopolitical imbalance in the publishing world. In between there is a large middle ground of small to medium-sized publishers who are committed to translating children's literature. They are often fuelled by idealism, but nonetheless justifiably want and need to make a commercial success of their enterprise. Amongst these is Klaus Flugge founder of Andersen Press in London in 1976, and tireless advocate of translations, who bought picturebooks from France, Sweden, and Germany for the 26 UK market (Flugge). ${ }^{24} \mathrm{He}$ has been followed by a new generation of publishers who have, within the past two decades, founded small-scale independent presses such as Pushkin Press or Tiny Owl Publishing in Britain, or in New Zealand Gecko Press. ${ }^{25}$ In Ireland, author turned translator and publisher Siobhán Parkinson ${ }^{26}$ set up Little Island Press in 2010. She gives expression to the kind of commitment behind this work; she believes "passionately in the importance of making books available to children that bring them the message that not everyone interacts with the world through the medium of English" (Parkinson 2015). With this she follows in the footsteps of Aidan Chambers, Hans Christian Andersen Award winning author, who championed translated fiction, and co-founded a small children's press with an Australian partner in 1988, dedicated to publishing modern European children's literature in translation, Although short-lived (it ceased trading in 1992), Turton and Chambers produced several acclaimed translations and was an inspiration for many of the newer enterprises (Berry).

On the level of organizations that support translation, we have, on the one hand, national agencies for the arts, who offer grants and subsidies to foreign publishers to assist translating literary works by authors from their countries into other languages. Their answer to the question "why?" is straightforward: to promote their language(s) and culture(s) internationally. This kind of financial support is vital for small publishers who might not otherwise be in a position to fund the translation of a novel from another language without significant subsidy. On the other 
hand are charities and non-profit organizations who work to promote translations. Examples in Britain are BookTrust, the UK's largest children's reading charity, ${ }^{27}$ whose "In Other Words" project works to help publishers find and acquire children's books in translation; “Outside In World“, an organization dedicated "to promoting and exploring world literature and children's books in translation", ${ }^{28}$ or the educational project "Translation Nation", funded by the Stephen Spender Trust and the Eastside Educational Trust, that sent translators into inner-city primary schools to have the children find out more about the work of a translator and to make translations themselves of folk tales from other cultures. ${ }^{29}$

The oldest and largest international non-profit organization committed to bringing books and children together, whose mission is to promote international understanding through children's books, is the International Board on Books for Young People (IBBY). ${ }^{30}$ It has been engaged in "cultural bridge building work" since it was founded in 1953. By awarding prizes and through the IBBY Honour List of recommended titles, it works towards increasing the number of translations and foreign editions of excellent children's books. Similar mediation work is carried out by the International Youth Library in Munich (IYL), whose annual White Ravens catalogue recommends for translation a selection of 200 titles of children's books in all languages.

Prizes, too, have an important function in fostering and recognizing translation. When Germany's state-funded children's literary award, the "Deutscher Jugendliteraturpreis" was set up in 1956, it was the cultural policy to include translations on equal terms with books by German authors, with the translator awarded and listed as co-author. It is the only state prize worldwide allowing this parity. ${ }^{31}$ Specific prizes have also been set up to raise the profile of translated children's literature. These include the annual Mildred L. Batchelder Award in the United States, named for the librarian and tireless advocate of translation, Batchelder. The Astrid Lindgren Prize, based on a generous donation made by the author herself, was set up in 1981 to promote the translation of children's literature; it is awarded trienially (by the International Federation of Translators's (FIT)) for a single translation of outstanding quality or for an entire body of work.

That brings us finally to those whose work is honored by these prizes, the translators themselves, and I will end this section with these unsung and usually underpaid heroes and heroines of international cultural exchange, without whom there would be no translation. Very often we don't even know who they were, as up to the mid-20 $20^{\text {th }}$ century they often went unnamed. This lack of accreditation, corresponding to the general low status of children's 
books, makes translators for children what Gillian Lathey has called "the great disappeared of literary history" (Lathey 2006, 209). In The Role Of Translators In Children's Literature. Invisible Storytellers (Lathey 2010) Lathey makes these translators less invisible, casting light into the dark history of why translators translate. Financial reward and status (especially for pre-20th century women) naturally play a role, but translators' prefaces and other paratexts often reveal a motivation based on the texts themselves. It can be "because their moral messages matched those in her own publication for children" - as in the case of Wollstonecraft's Salzmann translation (Lathey 2006, 7), or to "reintroduce imaginative stories into children's lives" (ibd.) - as in the case of Edgar Taylor translating Grimms' fairy tales into English, or it can be a touching personal reason, such as Joan Aiken's for retranslating the Comtesse de Ségur's L'Auberge de L'Ange-Gardien, because she encountered the stories "as a child, read in French by her mother" (ibid.). These are just brief examples of the varying factors that may motivate translators to translate (a specific text) for children.

\section{Conclusion}

What I have attempted to do within the limits of this article is to present a basic map of the field of translating for children (see Figure 5), to give a rough account of the multitude of different, at times conflicting, forces and interests at work behind the seemingly simple question "why translate children's literature?"

Figure 5 - Why translate children's literature: a basic map

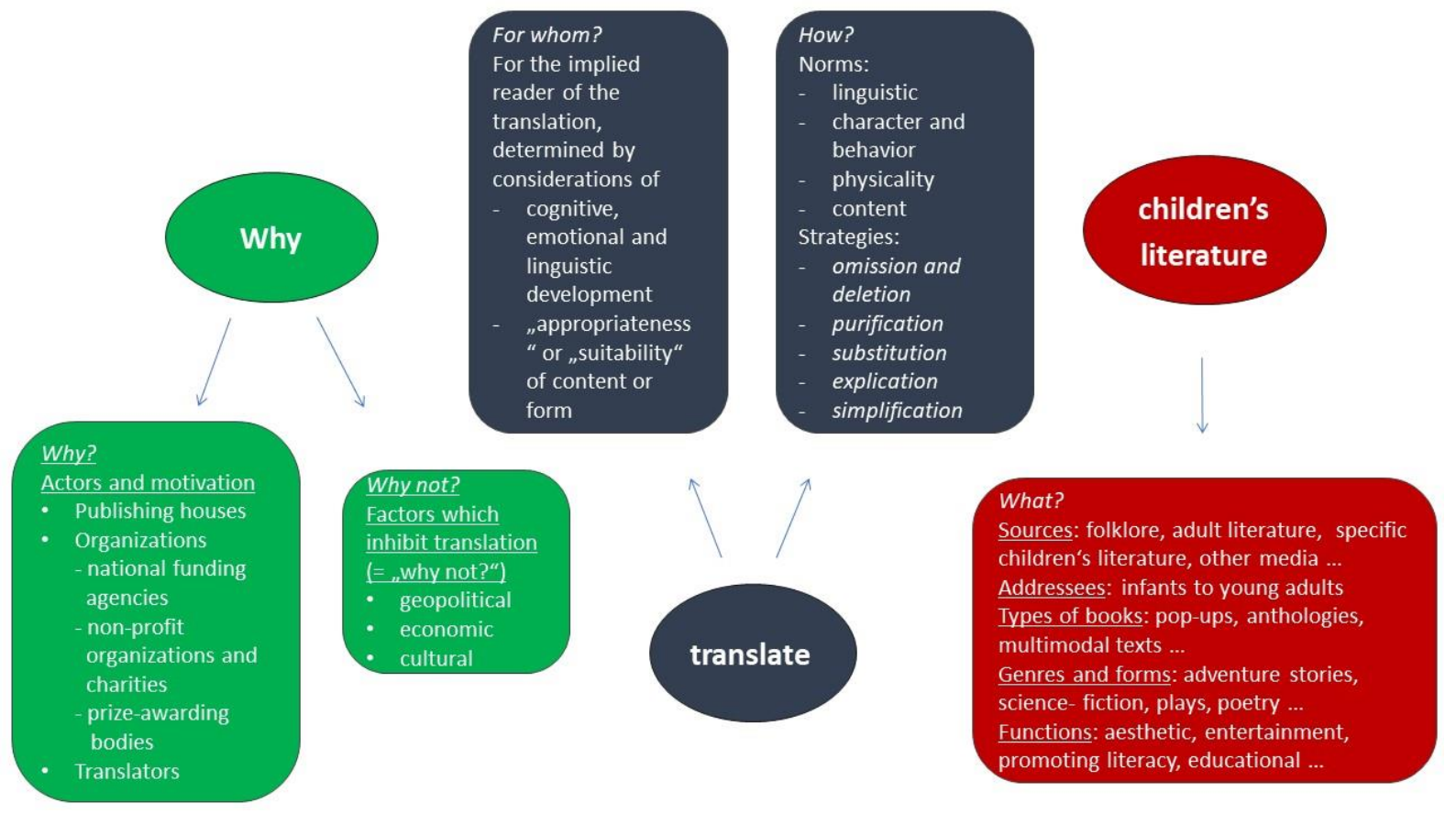


No less heterogeneous than the kinds of texts and the different addressees contained in the corpus of "children's literature" are the considerations for whom it is translated, considerations that determine the configuration of the implied readers, as well as how texts are translated for them. Finally, the "why" was adressed, the motivation of human and non-human actors who translate or support the promotion, translation, and international circulation of children's books, as well as the factors that inhibit or even prevent translation. In discussing these factors, we have encountered literatures that consider themselves so rich that they feel little need to search beyond their vast linguistic borders, and others that struggle to establish themselves under difficult geopolitical circumstances. We have seen the purely economic motivation of global conglomerates and the idealism of those who believe passionately in the importance of translations. Any account of the complex field of translating for children today must consider all of these conflicting forces in order to get a differentiated picture of the field.

I will finish with a statement by a translator and publisher, because without these two professions there would be no translated literature for children. Siobhán Parkinson, who combines both roles, provides a fitting conclusion to this article that has asked "why translate children's literature". Her answer: "it is tremendous fun and hugely worthwhile" (Parkinson 2016).

\section{WORKS CITED}

Alvstad, Cecilia. "Publishing Strategies of Translated Children's Literature in Argentina: A Combined Approach.” Meta : journal des traducteurs / Meta: Translators' Journal, vol. 48, 1-2, 2003, pp. 266-75.

Alvstad, Cecilia. “Children's Literature." Routledge Handbook of Literary Translation, edited by R. Kelly Washbourne and Ben van Wyke, Routledge, 2019, pp. 159-80.

Ambatchew, Michael Daniel. "International Communities Building Places for Youth Reading." Handbook of Research on Children's and Young Adult Literature, edited by Shelby Wolf et al., Routledge, 2011, pp. 430-38.

Baker, Mona and Gabriela Saldanha, editors. Routledge Encyclopedia of Translation Studies, Routledge, 2011.

Beauvais, Clémentine. “Translated into British: European Children's Literature, (In)difference and Écart in the Age of Brexit." Bookbird: A Journal of International Children's Literature, vol. 56 , no. 1,2018 , pp. 10-18.

Becchi, Anna. "I Am a Translator, a Transmitter of Culture." Bookbird: A Journal of International Children's Literature, vol. 56, no. 1, 2018, pp. 62-64. 
Berry, Charlotte. "Quality not Quantity": The Role of the Editor and the Language Consultant in the English Translations of Swedish and Norwegian Children's Fiction at Turton \& Chambers, 1988-92." Mémoires du livre, vol. 9, no. 1, 2017.

Büchler, Alexandra, and Giulia Trentacosti. Publishing translated literature in the United Kingdom and Ireland 1990 -2012: Statistical report. 2015, www.lit-across-frontiers.org/wpcontent/uploads/2013/03/Translation-Statistics-Study_Update_May2015.pdf.

Čermáková, Anna. "Translating Children’s Literature: Some Insights from Corpus Stylistics.” Ilha do Desterro, vol. 71, no. 1, 2018, www.scielo.br/scielo.php?script=sci_arttext\&pid= S2175-80262018000100117.

Chambers, Aidan. "In Spite of Being a Translation." Reading Talk, edited by Aidan Chambers, Thimble Press, 2001, pp. 113-37.

Cullen, Catherine Ann. "All Better! Rewriting a Latvian children's book for an Irish audience." The Irish Times, 28 May 2019, www.irishtimes.com/culture/books/all-better-rewriting-alatvian-children-s-book-for-an-irish-audience-1.3907094. Accessed 9 June 2019.

Desmet, Mieke K.T. Babysitting the Reader: Translating English Narrative Fiction for Girls into Dutch (1946-1995), P. Lang, 2007.

30 Fernández López, Marisa. "Translation Studies in Contemporary Children's Literature: A Comparison of Intercultural Ideological Factors." Children's Literature Association Quarterly, vol. 25, no. 1, 2001, pp. 29-37.

Flood, Alison. "Pushkin launches new imprint for children's books in translation." The Guardian, 07. May 2013, www.theguardian.com/books/2013/may/07/pushkin-imprintchildrens-books-translation. Accessed 8 June 2019.

Flugge, Klaus. “A Publisher's Perspective.” Hallford and Zaghini, Hallford et al. 2005.

Ghesquiere, Rita. "Why Does Children's Literature Need Translations?" van Coillie and Verschueren, Children's Literature in Translation, 2006, pp. 19-33.

Hahn, Daniel. Award-winning translator Daniel Hahn ponders the importance - or otherwise of 3\%. Booktrust. 2007, www.booktrust.org.uk/books-and-reading/translated-fiction/ articles/daniel-hahn/.

Hallford, Deborah. A Decade in Children's Literature in Translation (2005 - 2014). 2016, www.outsideinworld.org.uk/childrens-books.asp?page=ArticlesNewsandLinks. Accessed 7 June 2019.

Hallford, Deborah, and Edgardo Zaghini, editors. Outside in: Children's books in translation, Milet, 2005, www.outsideinworld.org.uk/childrens-books.asp?page=publications-outsidein.

Heilbron, Johan. "Towards a Sociology of Translation: Book Translations as a Cultural World System." Critical Readings in Translation Studies, edited by Mona Baker, Routledge, 2010, pp. 304-16. 
Jensen, Eline Morch. "Communicating the Strange: The entire world into the kids' room and the class room ...". KLODSHANS, July 2012, 2012, pp. 18-22.

Ketola, Anne. "Picturebook Translation as Transcreation." In Search of Meaning: Literary, Linguistic, and Translational Approaches to Communication, edited by Hanne Juntunen et al., Universität of Tampere, 2018, pp. 127-43.

Kreller, Susan. Englischsprachige Kinderlyrik: Deutsche Übersetzungen im 20. Jahrhundert, Lang, 2007.

Lathey, Gillian. "The Translator Revealed. Didacticism, Cultural Mediation and Visions of the Child Reader in Translator's Prefaces." van Coillie and Verschueren, Children's Literature in Translation, 2006, 1-18.

Lathey, Gillian. The Role of Translators in Children's Literature: Invisible Storytellers, Routledge, 2010.

Lathey, Gillian. "Serendipity, Independent Publishing and Translation Flow: Recent Translations for Children in the UK." The Edinburgh Companion to Children's Literature, edited by Clémentine Beauvais and Maria Nikolajeva, Edinburgh University Press, 2017, pp. 232-44.

Lepman, Jella. A Bridge of Children's Books: The Inspiring Autobiography of a Remarkable Woman. Translated by Edith McCormick, O’Brien Press, 2002.

Marcus, Kendra. "Buying and Selling International Children's Book Rights. A Literary Agent's Perspective.” Publishing Research Quarterly, vol. 19, no. 1, 2003, pp. 51-56.

Martin, Ruth. Remembering Anthea Bell. New Books in German. 2019, www.new-books-ingerman.com/remembering-anthea-bell. Accessed 15 June 2019.

McGillis, Roderick. The Nimble Reader: Literary Theory and Children's Literature. Twayne Publishers, 1996

McMartin, Jack, and Jan van Coillie, editors. Children's Literature in Translation: Texts and Contexts, University of Leuven Press, forthcoming.

Mdallel, Sabeur. "Translating Children's Literature in the Arab World: The State of the Art." Meta: journal des traducteurs / translators' journal, vol. 48, 1-2, 2003, pp. 298-306.

Millán-Varela, María del Carmen. "(G)alicia in Wonderland: Some insights.” Fragmentos, janjun, 1999, pp. 97-117.

Oittinen, Riitta. Translating for Children, Garland, 2000.

O'Sullivan, Emer. "Translating Pictures. The Interaction of Pictures and Words in the Translation of Picture Books.” Signal, no. 90, 1999, pp. 167-75.

O'Sullivan, Emer. "Narratology meets Translation Studies, or, The Voice of the Translator in Children's Literature." Meta, vol. 48, 1-2, 2003, pp. 197-207. 
O’Sullivan, Emer. Comparative children's literature, Routledge, 2005.

O'Sullivan, Emer. "Two languages, two children's literatures: translation in Ireland today." Children's Literature in Translation: Texts and Contexts, edited by Jack McMartin and Jan van Coillie, University of Leuven Press, forthcoming.

Nel, Philip and Lissa Paul, editors. Keywords for Children's Literature. NYU Pres, 2011.

Parkinson, Siobhán. "English than that for me! Publishing children's books in translation." Children's Literature on the Move: Nations, Translations, Migrations, edited by Nora Maguire and Beth Rodgers, Four Courts Press Ltd, 2013, pp. 151-60.

Parkinson, Siobhán. "Happy $5^{\text {th }}$ birthday, Little Island: Siobhán Parkinson traces the history, successes, challenges and ambitions of the children's publisher she helped found in 2010 as it launches its $50^{\text {th }}$ book." The Irish Times, 13 May 2015, www.irishtimes.com/culture/ books/happy-5th-birthday-little-island-1.2211315. Accessed 6 Feb. 2019.

Parkinson, Siobhán. "Watch out for the Umlauts! Children's Books in Translation from Little Island." writing.ie. The complete online writing magazine, 28 Apr. 2016, www.writing.ie/ interviews/children-young-adult/watch-out-for-the-umlauts-childrens-books-in-translationfrom-little-island-by-siobhan-parkinson/.

32 Plenge, Vagn. "Getting books from south to north." Peace through children's books. Proceedings of the $26^{\text {th }}$ congress of the International Board on Books for Young People, New Delhi, India, 20.24 Sep., 1998, Association of Writers and Illustrators for Children, [1999], pp. 420-29.

Salisbury, Martin C. "No red buses please: International co-editions and the sense of place in picturebooks." Bookbird, vol. 44, no. 1, 2006, pp. 6-12.

Seifert, Martina. "The image trap: The translation of English-Canadian children's literature into German." Children's Literature Global and Local: Social and Aesthetic Perspectives, edited by Emer O’Sullivan et al., Novus Press, 2005, pp. 227-39.

Shavit, Zohar. "Translation of Children's Literature as a Function of its Position in the Literary Polysystem.” Poetics Today, vol. 2, no. 4, 1981, pp. 171-79.

Sinibaldi, Caterina. "Pinocchio, a Political Puppet: the Fascist Adventures of Collodi's Novel." Italian Studies, vol. 66, no. 3, 2011, pp. 333-52.

Steiner, Ann. "The Global Book: Micropublishing, Conglomerate Production, and Digital Market Structures." Publishing Research Quarterly, vol. 34, no. 1, 2017.

Stephens, John. Language and Ideology in Children's Fiction, Longman, 1992.

Stolt, Birgit. "How Emil Becomes Michel: On the Translation of Children's Books." Children's Books in Translation, edited by Göte Klingberg et al., Almqvist \& Wiksell International, 1978, pp. 130-46. 
St-Pierre, Paul. "Translation as a Discourse of History." TTR : traduction, terminologie, rédaction, vol. 6 , no. 1,1993, p. 61.

Tang, Rui. "Chinese Children's Literature in the $21^{\text {st }}$ Century." Bookbird, vol. 44, no. 3, 2006, pp. 21-29.

Thomson-Wohlgemuth, Gaby. Translation under State Control: Books for Young People in the German Democratic Republic, Routledge, 2009.

TRANSLATION. Daniel Hahn advocates for children's literature [Interview]. 2019, www.wordsandpics.org/2019/04/translation-danny-hahn.html. Accessed 9 June 2019.

Tucker, Nicholas. "Why is There a British Problem?" Hallford and Zaghini, Hallford et al. 2005.

van Coillie, Jan, and Walter Verschueren, editors. Children's Literature in Translation: Challenges and Strategies, St. Jerome Publishing, 2006.

van Coillie, Jan, and Walter Verschueren, editors. "Editors' Preface." van Coillie and Verschueren, Children's Literature in Translation, pp. v-ix.

Venuti, Lawrence. The Translator's Invisibility. A History of Translation, Routledge, 1995.

Washbourne, R. Kelly and Ben van Wyke, editors. Routledge Handbook of Literary Translation, Routledge, 2019.

\footnotetext{
* Emer O’SULLIVAN - Professor of English Literature at Leuphana University, in Lüneburg, Germany. Post Doctorate in Comparative Literature (1999) at Johann Wolfgang Goethe-Universität Frankfurt, Germany). PhD in German Literature (1987) at Freie Universität Berlin, Germany. MA in German and English (1984) at Freie Universität Berlin, Germany. BA in English, German and Spanish (1980) at University College Dublin, Ireland. Lüneburg, Germany.

Her book Kinderliterarische Komparatistik (Winter 2000) won the the biennial IRSCL Award for outstanding research and Comparative Children's Literature (Routledge 2005), won the Children's Literature Association 2007 Book Award. Her most recent publication is Imagining Sameness and Difference in Children's Literature (co-edited with Andrea Immel). She is currently working on an updated and expanded edition of Historical Dictionary of Children's Literature (Scarecrow Press).

Academic Curriculum: https://www.leuphana.de/en/institutes/ies/staff/emer-osullivan.html

ORCID: https://orcid.org/0000-0001-6178-0774

E-mail: osullivan@uni.leuphana.de

${ }^{1}$ An early version of the "map" introduced here was presented in my plenary lecture at the 33rd International IBBY Congress 'Crossing Boundaries: Translations and Migrations' in London in August 2012. A recording of the lecture can be seen at https://www.youtube.com/watch?v=2zTH5dagKUg

${ }^{2}$ See the discussion in Ghesquiere.

3 Jella Lepman established the International Youth Library in Munich in 1949 and, in 1953, co-founded the International Board on Books for Young People (IBBY) in Zurich, Switzerland.

${ }^{4}$ It was snapped up so quickly that Lepman didn't even get to keep a copy for her files: "We paid dearly to buy some back from the black market, where Ferdinand finally wound up as a prize object" (Lepman)

${ }^{5}$ Lepman also encouraged Erich Kästner to translate Clement Clarke Moore's poem „Twas the Night before Christmas", that was then published in special Christmas issue of a German magazine.
} 
${ }^{6}$ See, for instance, Stephens, McGillis, Rudd, or Nel and Paul.

${ }^{7}$ See, for instance, Baker and Saldanha or Washbourne and van Wyke

${ }^{8}$ They have been a special focus of interest in children's literature translation studies. See for instance O'Sullivan 1999, Oittinen, or Ketola.

${ }^{9}$ That this is often an erroneous assumption is documented by numerous studies on what happens to picturebooks in translation. Sometimes publishers are taken with the illustrations and buy the translation rights, to go on to write completely new texts to "more accurately reflect what is being portrayed in those illustrations" (Marcus 55), telling a story to go with the pictures in a way they think is appropriate for their target readers.

10 Adam Freudhenheim from the Pushkin Press, one of the new independent British publishers that issues translations for children, remarked of the situation in the UK: "There are plenty of publishers doing picture books in translation, for children aged five and under [... but] no one's looking at books for five- to 10-year-olds, and 10plus." (Flood).

${ }^{11}$ O'Sullivan 2005, 13-19.

${ }^{12}$ However, when talking about manipulation in children's literature it is worth remembering that all translation, as a form of cultural practice, is "the regulated transformation of an original text" (St-Pierre 61) "a linguistic event produced by a subject within a specific historic context, [...] dependent upon laws and rules which determine not only what can be said but also the way in which it can be expressed" (62).

${ }^{13}$ See O'Sullivan 2005, 81-91 for examples.

${ }^{14}$ In one instance, Pippi's supernatural strength is reduced to what must have seemed, to the French publishers, a more "appropriate" level. Instead of lifting up a horse, Fifi Brindacier can only lift up a pony. When Astrid Lindgren protested, the French publisher wrote to her that while it might be possible to persuade little Swedish 34 children that someone is capable of picking up a horse, French children, who had just been through a world war, had too much common sense to swallow such a tall tale. Lindgren responded by asking to see a photograph of a French child holding a pony in the air, but the publisher, unsurprisingly, never provided one. The French retranslation of Fifi by Alain Gnaedig in 1995 rectified this particular manipulation (Stolt).

15 The strict policy in modern US children's literature of not depicting nudity, irrespective whether of children, adults or even animals, is legendary. This has consequence for coproduced books in which norms of the dominant partner USA increasingly dictate what may and may not be shown in a picturebook (See Salisbury 2006).

${ }^{16}$ Hahn gives as an example a page of "silly little aphorisms about grandmothers, which rhyme, and for each of the rhyming aphorisms there's a picture - so I couldn't simply translate the aphorism at the risk of losing the rhyme, or just do something totally different at the risk of losing the connection to the illustration. So in each case, I had to make up an aphorism about grandmothers, which rhymed, and for which this existing image could still work as an illustration" (TRANSLATION).

${ }^{17}$ The publisher Siobhán Parkinson wrote: "People always want to know how we find our titles to translate. The answer is that it's mostly serendipity". (Parkinson 2016).

${ }^{18}$ See for the situation in China, Tang.

${ }^{19}$ It is very difficult to obtain exact statistics. The study by Literature across Frontiers established a 3\% proportion of translation in Britain and Irish literature overall, but did not provide separate figures for children's literature (Büchler and Trentacosti).

${ }^{20}$ According to statistics from the municipal library in Prague for the year 2012, 19 of the top 20 most borrowed children's literature were translations (Čermáková).

${ }^{21}$ Alvstad is one of the few children's literature translation scholars who has systematically pursued the question of non-translation (cf. for instance, Alvstad 2003).

${ }^{22}$ https://www.baobabbooks.ch/en/about_us/

${ }^{23}$ Plenge also draws attention to the paradox that, while many librarians and teachers praise him for publishing these original books, saying that they are really needed, they don't actually buy them, saying that, in their originality, they are "too difficult" for children to understand. 
${ }^{24}$ Flugge was the first to commission a translation from Anthea Bell in 1961, who would go on to become the most accoladed - and respected - British translator. The translation was Otfried Preußler's The Little Water Sprite for Abelard-Schuman (Martin).

${ }^{25}$ Lathey 2017 gives an account of these, based partly on interviews with the publishers.

${ }^{26}$ Siobhán Parkinson, apart from the publisher and translator she has now become, is an award-winning, and muchtranslated writer for children and teenagers in English and in Irish, and was Ireland's first Laureate na nÓg [Children's Laureate] from 2010-12.

${ }^{27}$ https://www.booktrust.org.uk/about-us/

${ }^{28}$ http://www.outsideinworld.org.uk/index.asp. See also Hallford.

${ }^{29}$ Clémentine Beauvais calls this "another prominent and fascinating development of the promotion of translation in the United Kingdom” (Beauvais 11). She comments further: "In the United Kingdom, translating children's books; publishing, promoting, and teaching such books; and in equal measure studying them are activities de facto so vividly anomalous, so stamped by commitment, as to require their own conceptual, aesthetic, and ideological frameworks for analysis." (Beauvais 11)

${ }^{30} \mathrm{http}: / / w w w . i b b y . o r g / a b o u t / w h a t-i s-i b b y /$

${ }^{31}$ A partial explanation lies in the mindfulness of the exclusion of all foreign works during the Nazi era, when almost nothing was translated, and the important contribution translations made towards establishing a new, untainted literature for young German readers after the end of the Second World War. 